\title{
Henrikas Nagys as a Mediator of Lithuanian and Latvian Poetical Traditions
}

\author{
MANFREDAS ŽVIRGŽDAS
}

\begin{abstract}
In this article, motifs, references and influences of Latvian descent in the poetry of Lithuanian Henrikas Nagys (1920-1996) who spent most of his creative life in Canada are observed and analyzed. Nagys was praised by critics as one of the main modernizers of the national poetical vocabulary; nevertheless he was regarded as one of the most emotionally suggestive and ideologically engaged poets of Lithuanian Western exile. He belonged to the Žemininkai movement which played an important role transforming lyrical tradition in the diaspora during the 1950s; the members of this group were deeply influenced by the post-Naturalist trends of Western Modernism and Existentialist philosophy; they were members of the generation which got educated in the gymnasiums of independent Lithuania. Nagys used to translate contemporary Latvian authors who had the similar experience and who adopted the mythic Baltic heritage but at the same time reflected some kind of Protestant simplicity and sobriety, natural vitalism and economy of expression. Nagys promoted Latvian poetical tradition introducing Velta Sniķere, Gunars Salinšs, Aina Kraujiete, Aina Zemdega, and Astrīde Ivaska in his Lithuanian translations. Simplified Latvian poetical style with its free versification, pure images and folklore-based models of spatial and chronological organization was reflected in Nagys' later poems. His links with Latvia were biographical, based on childhood memories; however his imaginary landscape was a result of fusion of universal Northern features. Nagys popularized the symbolism of the North, and Latvian place-names were included into the map of his identity.
\end{abstract}

Keywords: boundary literature, Latvian poetry, Žemininkai movement, Modernism, regionalism, literature of Western exile, émigré community, alienation, nostalgia

\section{Latvian Traces in the Lithuanian Poet's "Map" of Identity}

Distinguished men of letters in general are regarded as extraordinary mediators of cultures, especially those who are engaged in translations. Poetical creation could be defined as an exception out of the system of common language and as an embodiment of Roman Jakobson's theory of poetical function of language 
as a function which refers to the language itself. Therefore a problem of untranslatability appears inescapable: poem could be interpreted as a hermetic universe and it would never be transposed into different system of meanings adequately. According to the theorist of translation Rainer Schulte, "[c]reation in whatever form presupposes some kind of discontinuity, a degree of disruption. Whatever the new creation might be, it constitutes a difference to what there was before" (Schulte). While in the process of translation of poetical texts, the symbolism and imagery of a different creative tradition should be adopted. If a poet is multilingual he can let different traditions communicate in his or her oeuvre; the dialogue of related or distant semantic systems enables the native poetical vocabulary to renew itself.

The literary tradition of Latvian post-war exile diaspora in the West was newly discovered in Latvia in the post-Soviet era, after the long period of compulsory "silent treatment". These texts and most of their authors are not well known in neighbouring Lithuania. The most notable of them is Astrīde Ivaska (together with her husband, internationally renowned Estonian poet and literary critic Ivar Ivask). The joint book of this fabulous pair of poets was recently published in the Lithuanian language (Ivaska, Ivask 2007; the collection of poems and concise reviews of Latvian and Estonian literary traditions in exile was compiled by the enthusiast of Baltic-Scandinavian cultural relations, Silvestras Gaižiūnas). During the 1950s and 1960s Ivask had epistolary contacts with the Lithuanian poet Henrikas Radauskas; they both were interested in Lithuanian poetry and considered it to be a part of Finno-Baltic cultural complex. Solidarity of the Baltic émigré writers of the same generation was unsurprising: though living in different cities and continents they were linked together by similar memories of the past, the traumas and depressions, nostalgia and a sense of alienation. They promoted coherent projects of "westernization" of their native poetical traditions.

Henrikas Nagys (1920-1996) was a poet, essayist, journalist of the diaspora media and author of significant books of poetry Lapkričio naktys (November Nights, 1947), Saulès laikrodžiai (Sundials, 1952), Mèlynas sniegas (Blue Snow, 1960), Broliai balti aitvarai (Brothers White Kites, 1969), Prisijaukinsiu sakala (I Will Tame a Falcon, 1978); nevertheless he was not incorporated into the stable canon of Lithuanian literary history, partly because of the uneven value of his later poems. He was also regarded as an expert of Latvian poetry as he published some translations and a short review of it. Nagys' poetical charisma impressed his sister Liūné Sutema (1927-2013) who translated modernist Latvian poetry into Lithuanian and even included Gunars Saliņš few verses in original language into her own poem "Vigilija" ("The Vigil") (Sutema 2009: 98): "Pa to laiku priekšā / iznācis Dievs / un ap altāŗra telpu, ap krustu / būvē plūdus: / 
zilus viḷṇus, zaḷus viḷnus - / augstāk, / augstāk, / augstāk, / augstāk" ("In the meantime God came out and there was flood around the altar, around the cross: blue waves, green waves - higher, higher, higher, higher" - my translation, M. Z..). The universal biblical myth of the Great Flood interpreted in the poetic Latvian stanza was identified as evidence of the coherence of the narrative models recognized in the Christian Holy Scripture and Baltic poetical symbolism. Aside from the brother and sister Nagys and Sutema, there were also attempts of literary comparative studies regarding Baltic poets: for instance, Rimvydas Šilbajoris analyzed the relations of aesthetical and emotional fields of expression in the poetry of Saliņš and Radauskas (Šilbajoris 1982). Nevertheless those efforts of cultural collaboration of the two Baltic nations were rather accidental, though there were many joint cultural events organized in the Western Hemisphere, and poets were personally acquainted with each other.

How are we able to identify specific "Latvian" semantic figures? First of all we pay attention to the place-names and hydronyms: from the era of the national revival of the $19^{\text {th }}$ century Lithuanian literature reflected national identity which referred to the patterns of topographical identification and imagination, and these patterns transformed the significant part of national literary geopolitics (Butkus 2008: 27). The poets of exile meditated on the private landscape inherited from their childhood and were not content with the status of provincial chroniclers: for example, Alfonsas Nyka-Niliūnas (who settled in Baltimore, USA for the latter sixty years) reconstructed his native village of Nemeikščiai as the final point of mythical "eternal return", and it appears in great many of his poems and essayist diaries as the symbol of Eldorado, Arcadia, or Paradise Lost (Butkus 2010:39). In Nagys' poetry there were also many landscapes related to northern Lithuania, though they seem not so repetitive or turning into metaphysical symbols; this poet was not so deeply "enrooted" in the concrete region.

The balance of modernist and conservative trends in the history of every national literature depends on the individual authors. However the expert of comparative literary studies Ivask stated that there were more stylistic kinship between Latvian and Lithuanian exile poetry of 1944-1960 (especially between the trio of Nagys, Nyka-Niliūnas and Jonas Mekas on one side and Gunars Saliňš, Linards Tauns and Aina Kraujiete on the other side) comparing to the intellectually inspired, well-balanced Estonian texts of the same period: "Lithuanian imagination had been enriched by the Catholic belief that the Word really was incarnated into the Body. Perhaps therefore Latvian and Lithuanian poetry turned out to be more flamboyant, intuitive, lyric and mystic than the Estonian one" (Ivask 1973: 9). Certainly, such generalizations sound superficial or trivial nowadays. 
Further down in this article, examples of Latvian poetry are translated into the English language word-for-word from translations into Lithuanian made by Nagys, so that alterations of meaning are possible regarding the effect of double translation. We did not try to estimate the degree of adequacy of translation or to explain the position of those few texts in the canon of Latvian poetry in general. Whether those translated poems are typical examples of individual style or not, they represent the diversity of modernist Latvian poetry (therefore many of them were published in the main cultural magazine of the Lithuanian exile in the USA Aidai (The Echoes) on the occasion of the $50^{\text {th }}$ anniversary of Latvian Independence in 1968). It seems difficult to assert that translations of Latvian poems influenced Nagys' metaphoric vocabulary and figurative level of expression directly, as the chronological order of translations was not clear. Nagys was a seeker for universal "brotherhood" of creative geniuses and at the same time his controversial, egocentric character provoked him to involve into disputes and clashes with his colleagues. He paid attention to the poets who belonged to the same generation and had had similar biographical experiences.

On the other hand, Nagys was scared by the idea that some critics could find some foreign influences in his works. His friend and poet of the same Žemininkai generation Alfonsas Nyka-Niliūnas (b. 1919) while reviewing Nagys' collection of poems Saules laikrodžiai (Sundials, 1952) stressed the influence of Friedrich Nietzsche and all post-naturalist German poetry: "His [Nagys'] sources culturally tend to be international rather than Lithuanian. While most of us [during the pre-war epoch and the years of WWII] lied obstinately in the anti-Western secure coverts, Henrikas Nagys in his poems sought for support and for individual point of view in the 'hearths' of his own intellectual culture" (Nyka-Niliūnas 1996: 296). A benevolent critic preferred to define stylistic differences rather than analogies: he excluded the possibility of the formal influence of Rainer Maria Rilke, Stefan George or Hugo von Hofmannsthal in Nagys' case. Later Nyka-Niliūnas confirmed that the fashionable slang of German-oriented poetry was characteristic of the whole generation of Lithuanian "existentialists" (i.e. to those who studied philosophy of Martin Heidegger and Karl Jaspers in the wartime Vilnius and Kaunas universities under the supervision of Dr. Juozas Girnius). Nagys was remembered as the developer of the theatrical and pathetic image of the Nietzschean poetical genius (Nyka-Niliunas 1998: 3). On the other hand, he was appreciated as a radical modernizer of conservative Lithuanian Neo-Romanticist lyrical tradition, "one of the creators of the modern vocabulary of Lithuanian poetry” (Kaupas 1963).

Aside from Nyka-Niliūnas who regarded Rilke, George and Hofmannsthal as "antipodes" contrasting the spontaneous spirit of Nagys, other critics generally emphasized Nagys' motifs which could be adopted from German or Austrian 
ŽVIRGŽDAS

Symbolism and Expressionism. Latvian influences remained unexplored as most of the literary reviewers knew only basic facts about the poetical context of the Baltic neighbours. From the times of the pre-war intellectual circles there were many projects of joint Baltic cultural initiatives but they remained unrealized. The critics used to emphasize the mysticism of the North, the Samogitian reticence and idyllic images that were saved from fragmented memories of childhood; Nagys' poetical geography of the North naturally embraced Latvian references too.

Nagys thought that writing poetry in the Lithuanian language under the conditions of exile should be considered as a special mission, the act of civil consciousness; he felt himself responsible not only to a compact Montréal-based community of Lithuanians but also to those who suffered under the totalitarian Soviet regime at home and had no chance to express themselves. The nationalist and Romanticstyle pathos of his later poetry and journalism fixated the steady image of Nagys in the collective memories of his contemporaries. During the revolutionary days of the national awakening in 1988-1990 when events in the Baltic States attracted the attention of the worldwide mass-media, his friends - as for instance his contemporary and neighbour in Montréal Vytautas A. Jonynas recalled - sighed with similar thoughts: "Let's imagine how happy Henrikas should be today!" "As if he had been the only person who was devoted to Lithuania and as if he achieved the monopoly of patriotism" (Jonynas 2006: 636). Latvian roots in this context could be regarded just as pure curiosity, some kind of private regionalism.

\section{Balancing at the Boundary of Cultures}

Nagys was born in Mažeikiai, northern Lithuania; this small provincial town was a strategically significant hub of communications and transit from the Tsarist times: it was crossed by the railway line which linked Warsaw to St. Petersburg. As a child, Henrikas spoke Lithuanian, Latvian and German fluently and later he was well acquainted with Latvian culture. He belonged to the community which in the second half of the $20^{\text {th }}$ century became the object of interest of the so-called "boundary literature" (Grenz-Literatur, theoretically defined by Dieter Lamping and represented by Johannes Bobrowski, Paul Celan, Czesław Milosz et al.). The concept of the boundary means the place for difference and the space where subject meets the symbolic figure of "the Other"; there is also the space of interaction, integration and fusion. The experience of the boundary is traumatic and related to the existentialist liminal situations, to the crossings of frontiers and to Georg Simmel's definition of human person as a "limited being who has no any limits / boundaries" (Butkus 2008: 21-22). 
The poet's origins were mixed; therefore he was frequently nicknamed "skerslatvis" ("semi-Latvian") by his friends (Jonynas 2006: 629). His mother Antanina Elfrida Grundmanis (1894-1986) was a daughter of a Latvian blacksmith who came to work in the growing pre-war town and important hub of railway transport, Mažeikiai. At the home of Nagys' parents a very particular role was played by Antanina's stepmother Emilija Peters-Grundmanis (1865-1952), the daughter of a miller and bee-keeper from the Liepāja region. She was regarded as a representative of the Germanophile literary tradition and was proud of her double Latvian and German origin; she was also famous in the town as an expert of homeopathic remedies (Paplauskiene 2009: 22-23). The poet's grandmother used to quote classical stanzas of Schiller and Goethe and influenced the cultural education of Antanina's children - two of them, Henrikas and his younger sister Zina Nagyte (aka Liūnè Sutema, 1927-2013) later became famous Lithuanian poets; Sutema was awarded the National Prize of Lithuania for her poetical works in 2007. It is known that while translating poetry from Latvian Nagys asked his grandmother Emilija for advice (Antanaitis 1970: 397).

Later Nagys dedicated a poem to his mother and revealed the secret matricentric symbolism of the earth (poem "Mother" / "Motina", Nagys 1990: 273 [1976]): mother and earth are treated as the closest sisters and they are deeply involved in collaboration. Mother runs around the earth every day, reviving the agricultural rituals "from the Lake of Liepāja to the fields of Lemont"; her existential trajectory includes the entire globe, from homeland Latvia to the foreign city of Chicago. Mother looks at the earth with creative insight: "Tu norètumei visą ją / apsèti, išglostyti, nuravèti" ("You want to sow, to caress, and to weed it all"). Concern about the earth, soil and roots can be related to the agrarian and conservative tradition of culture. On the other hand, Nagys never experienced the life of a traditional sedentary peasant: his father was a railway worker, and the family had to migrate between various regions of Lithuania during his young years. The space of the railway station was meditated as a universal boundary which should be crossed or left aside and which provoked longing. Mother in this world of dynamic changes and losses is defined as the guardian of permanent values.

In pre-war Lithuanian Northern province the principal texts of Western Modernism were acquired through Latvia: seventeen years-old Nagys read Rilke's sonnets from the two volumes of his Gesammelte Werke, which were brought by his aunt from Liepaja. By that time he was inspired by the depth of visionary lyrics and tried to discover the reason for its emotional impact: "This was a real discovery: How can he [Rilke] say it? You read it and you almost feel how it hurts" (Nagys 1991: 11). 
ŽVIRGŽDAS

Nagys spent the greater part of his life far away from his homeland: he read for a doctoral degree in the post-war universities of Austria and Germany during the period of 1944-1949, defended a thesis for the doctoral degree about the Expressionist poetry of Georg Trakl at Innsbruck University (and was among the first explorers of Trakl's poetics who sought the academic level of interpretation). Later he moved to Montréal, Canada and taught the Lithuanian language in the private schools of the diaspora. Nagys as a member of the Žemininkai movement tried to revive post-Romantic symbolism and to resume the experience of Western modernism in the ruins of World War Two. His specific metaphorical landscape was often related to the austere topography of the small towns and villages of Samogitia, but it was also characteristic of the boundary region of Latvia: there are "plains of the dreams" where during the dark nights "the endless heartbreaking laments pour down with the flows of rain, with winds, with painful winds" (poem "Villages in the Evening of Autumn") ("Širdị veriančios bekraštès raudos liejas / su lietaus srovèm, su vejjais, sopulingais vejjais", "Kaimai rudenio vakarą", Nagys 1990: 65 [1946]); where the rivers flow like veins of the earth ("O the rivers of the plains! You are glittering at the sun, you are wide and sleepy, and you stream from the boundless marshlands of the eastern horizon", poem "Rivers") ("Lygumų upès! Spindinčios saulèj, plačios ir tingios / srūvate jūs iš rytų horizonto bekraščių pelkynų”, „Upès“, ibid. 138 [1945]). The rivers that flow through Latvia (Mūša (Mūsa in Latvian), Venta) were mentioned in the series of visual impressions, and the name of Liepaja city was related to the interiors inherited from childhood and to their long-forgotten decorative figures (poem "Laterna magica”, ibid. 155 [1958]):

The cross of a window falls on the wall of uneven room.

The silhouettes of ships are swinging. Liepāja. A small statue of electric blacksmith forges and forges a piece of red iron.

The sailing-boats keep a vigil in a bottle. A copper-made pendulum shimmers evenly: light and shadow. A father's voice and the roar of great city. Night and silence.

Lango kryžius krenta ant kreivo kambario sienos. Linguoja laivų siluetai. Liepoja. Plaka ir plaka elektrinio kalvio maža statulèlè raudoną geležì. Budi stiklinèje bonkoje burlaiviai. Vario švytuoklè monotoniškai mirga: šviesa ir šešèlis. Tẻvo balsas ir didelio miesto ūžimas. Naktis ir tyla. 
This complex of images alludes to the photograph of double exposure where the sailing-vessels seen through the window blend with the toy-ships closed in the bottles. The idyll of the suspended moment and static objects is opposed to the monotonous rhythm of the mechanic pendulum and the playful figure of the electric blacksmith. The view of the port, just like the view of a busy railway station, could be identified as the repeating semiotic isotopy in the poetry by Nagys: both of them evoke nostalgia for the open space and unscheduled journeys, and both of them might be related to the childish impressions of the industrial city of Liepāja: "you would like to sail away leaving the port waters soaked with oil, its ships and snow which smells like the soil" (poem "The Lighthouse of a Small Port") ("tu norètumei išplaukt, palikęs persunktą aliejum / uosto vandenị, laivus ir sniegą, kvepiantị žeme”, “Mažo uosto švyturys”, ibid. 96 [1946]). The older poet Jonas Aistis criticized the repeated image of oil-stained water (very typical of Nagys' early poetical vocabulary) calling it an excessive poetical cliché (Aistis 2004: 376). Such images could be interpreted as symbols of urban civilization which blurred the clear and clean surfaces. They also seem to be the signs of technological progress characterizing the landscape of interwar Latvia.

\section{Fusion of Poetical Traditions in the Nuclear Era}

Nature was described in a particular way in the poems from the Saules laikrodżiai period: the space seems to be mobile; the rivers force their way to the sea roaring; the villages travel along the shores of the lakes; and the flamboyant autumn trees immediately invade the city to defend the innocent girl from the insults of vagabonds. Dynamics of nature is also common to Latvian poetry, especially to the exile writers who fill up nostalgic landscapes with surreal elements.

In the poetry by Aina Kraujiete (1923-2005) which was translated by Nagys, the tree of blue plums as the symbol of existential stability and fertility was planted into the depth of a stormy sea and turbulent clouds (poem "To Poet Who Was Loved by Gardens” / "Dzejniekam, kuru mīlēja dārzi”, Kraujiete 1968). A blue fruit of the plum tree could be considered a constant symbol of vitality in the Latvian poetical tradition (if we recognize poetical tradition only from Nagys' translations): it would be rediscovered in the poem "To Reality" by Astrīde Ivaska: "I soak into you like into a blue plum, reality, and I let the juice flow down the lips" (Ivaska, Ivask 2007: 46). Kraujiete dissociated herself from the static urban landscapes of New York City reflecting the impressions and reminiscences of visually dynamic nature. She created poetic mosaics out of fragments of the memories and visions (ibid. 29).

The colour of blue is equally important to Nagys, as it means the excess of vital strength and metaphorizes the secondary, alienated reality of exile, 
dominated by vivid colours and austere, plastic images: "We have found our land and our sky. / Blue land. Blue sky. Blue snow / between tough soil and soft clouds" ("Mes atradome savo žemę ir savo dangų. / Mèlyną žemę. Mèlyną dangų. Mèlyną sniegą / tarp kieto gruodo ir minkštų debesų") (poem "Blue Snow") ("Mèlynas sniegas", Nagys 1990: 145 [1959]). The poets of exile build their homes in new lands which are entitled terra incognita. The existence is fragile in the New World, and there is no place to root in: "In the land of blue snow there is no land" ("Mèlyno sniego žemej žemès nèra") (poem "Terra incognita”, Nagys 1963 [1959]). The living spaces lacking any references to the cultural traditions are built from crumbly materials; they never give the sense of comfort and security: "We will build our homes from wind, and they will swing in the branches of elm, [...] and we will give them our names" (poem "We Will Cry", Ivaska, Ivask 2007: 47).

The collection Mélynas sniegas (Blue Snow, Boston, 1960) differs from Nagys' earlier creative material; new topics, biblical allusions and intellectual reflections can be recognized there. The poetical language remained simplified, the laws of economy were emphasized. Nagys seems to be influenced by the Latvian poet Gunars Saliņš (1924-2010) and other members of the New York City "Hell's Kitchen” group who were highly impressed by American-English Imagist poetry (Ezra Pound, Thomas Stearns Eliot). The leading figures of Latvian "Hell's Kitchen" in the 1950s were the first literary generation of exile, just like Lithuanian Žemininkai. Latvian distinctive exile poets were a bit younger than their Lithuanian counterparts. The Latvian exile culture did not experience stylistic revolution in the first post-war years when the early collections of Nyka-Niliūnas and Nagys were published in 1946, still during the era of "barrack culture", in Germany and Austria. The beginning of Latvian exile Modernism was associated with the book of poems Miglas krogs un citi dzejoli (Inn of the Mist and Other Poems) by Saliņš (Brooklyn, NY, 1957). Such a long creative pause can be explained by the feelings of defeat and collapse which were common to Latvians after the downfall of the Courland stronghold in May of 1945, in the last days of World War Two (Ivaska's opinion: Ivaska, Ivask 2007: 20). "Hell's Kitchen" was the unofficial name of a district in Manhattan where the greater part of the Latvian diaspora settled. Saliņš had a vision about the reforesting of the American metropolis; the greenery could revive memories of the Latvian landscape. The poet's imagination was soaked in Baltic symbolism and established the visionary enclave or secluded island of ecological harmony, which was linked to the lost paradise of the homeland. Saliňšs attitude towards reality was full of sarcasm: his lyrical subject conceived that it was impossible to recreate the Latvian natural spirit amid metropolitan skyscrapers and that a poetical word was irrelevant in everyday discourse. This sarcasm influenced the 
system of versification: "An irreverent, blasphemous tra-la-la, jingling, hollowsounding internal rhymes, half-rhymes, assonances, awkward rhymes, colloquialisms, slang are facets of Salinšs search for authenticity and of his vibrant sensibility probing the ontological vacuum of the modern man" (Silenieks 1972).

Such aesthetic nihilism in general was alien to Nagys who contemplated the mission of the poet as testifying of civic duty. However, the pragmatic, businessman-oriented American worldview was reflected in some poems of Nagys' Mèlynas sniegas recalling Saliņšs's agnostic visions. Some of the images allude to the grotesque Expressionist-style posters, as for instance, "black-dressed clerks in the offices of Death who wax down the stairs to the cellar to make the falling [of a corpse] to the darkness slippery" "Juodi valdininkai mirties salonuose / vaškuoja laiptus ị rūsị: / slidus tebūna kritimas ị tamsą...” (poem "Imago mortis", Nagys 1990: 163 [1958]). The terrifying mask of imago mortis was inherited from the medieval tradition and Lithuanian catastrophist pre-war repertoire of Jonas Aistis; however, the irony of exile made Nagys closer to Salinšs, too.

Terra incognita which was found by Nagys could be recognized as the devastated landscape after the nuclear incident. Such a vision of apocalyptic wasteland derives from the stressful mood of the 1960s. The poet "therefore belongs among those modern poets whose modernity can be defined as despair. His is of the cold war generation which survived one catastrophe only to wait for the second, and ultimate, Armageddon" (Šilbajoris 1970: 230-231). The atomic threat was real at the time, but the feeling of lethal vacuum was related not only to the immediate mors atomica, rather to the hyperbolized alienation or incurable nostalgia of exiles. In this post-catastrophic and pre-catastrophic world only some kind of cynicism could help one to survive. It was difficult for Nagys to change his lyrical intonations and it was widely acknowledged by critics that his poetry had been "individualistic, idealistic and ideological" (Kaupas 1963). During the period of Melynas sniegas Nagys' worldview seemed losing all points of reference to the classical harmony, laws of symmetry and aesthetics. Some coherence might be recognized in the urban vision of Salinš which was full of remains, relics and fragments. There was no metaphysical hope for salvation or responsibility to the supreme powers, rather a cynical question: "how could I know what would be my appearance in heaven?” (Salinšs 1968). In the face of nuclear Apocalypse, Nagys' subject was treated like an animal and reflected the despair of condemned mankind. The main features of such a dehumanized society are amnesia and oblivion. Anonymous beings are deprived of memory as the last instrument of culture: "We are the beasts which the Scripture makes no mention of. / [...] No one has washed our names from naked sand" ("Mes esam žvèrys, šventraštyje neminèti. / [...] Mūsų vardų vanduo nenuskalavo smiltyje”) (poem “Mors atomica”, Nagys 1990: 168 [1959]). 
The Lithuanian-American literary critic Rimvydas Šilbajoris compared the poetical style of Saliņš to the ironic Neo-Classicist world-view of Radauskas which was not well-liked by Nagys for his so-called hermeticism and "the art for art's sake" philosophy; nevertheless Nagys translated both Saliņš and another representative of "Hell's Kitchen” Kraujiete. Nagys had always emphasized the intoxicating influence of Rilke's philosophical meditations; and Rilke was translated into Latvian by Saliņš and into Lithuanian by Nagys.

It would be an exaggeration to ascribe direct influences of Latvian Modernism to Nagys: he was impressed by the postwar turnovers of cultural life and absorbed many elements from American, German and Austrian Modernist tradition. The atmosphere of the 1950s and 1960s was exceptionally stressful: there was the obvious threat of atomic war, and the world was destabilized by the sexual and psychedelic revolution, the ideologically-based military conflicts in Korea and Vietnam, the interracial struggles and Marxist revolts in the Western universities. The foundations of the Western civilization were under constant attacks; and people thought they were living in the revolutionary era when the need for a new kind of poetry and art was obvious.

The ability of Latvian poets to blend the memory of natural landscape and the nervous rhythm of the multicultural contemporary city attracted Nagys. The poet wanted to amalgamate his emphasized national identity with openness to the world and all its exotic features: "Give me a chip of glass, let the dugouts sway in Granada, Bahia, Šventoji, under the smoky sun!” (poem "Favoured") ("Duokit man stiklo šukę: tegul, tegul supasi luotai / Grenadoj, Bahioj, Šventojoj, aprūkusioj saulejj!” “Išrinktieji”, ibid. 183 [1960]). The Latin American and Lithuanian place-names mix together in the reflections of imagination.

The riotous and cosmopolitan spirit of jazz music inspired by hippie-style "barefoot angels" of Los Angeles was familiar to Nagys; it is not important that carnival was celebrated in the desacralised, particularly mundane space where the celestial bodies reflected the senselessness of being: "The eye of the burnt out sun smoulders in the carnival flag"; "Artificial moons flee through the starless space” (poem “The Fifth Letter: Los Angeles”) (“Karnavalo oranžinèj vèliavoj smilksta išdeginta saulès akis"; "Dirbtiniai mènuliai skrieja bežvaigžde erdve”, "Penktas laiškas: Los Angeles”, Nagys 1963 [1960]).

A Latvian poetess Aina Zemdega (1924-2006), who lived in Sweden and Canada and was engaged in classical music, felt herself not responsible for the Latvian literary tradition. The improvisational mood and freedom of expression was typical of her poems of the 1960s. Ivaska shortly defined Zemdega's style: being a professional pianist she entered into literature "barefoot" and not weighed down by the conventional heritage, daring to explore the secret erotic 
side of human nature; this was an allusion to Zemdega's collection Basām kājām (Barefoot, Chicago, 1963) (Ivaska, Ivask 2007: 30). Nagys translated her poem "A Stroll" / "Pastaiga". Here jazz music was characterized as "shameful sounds" but the lyrical subject goes to listen to them to the café, under the intimate aura of the candles. Zemdega's lyrical subject identifies herself with the aficionados of jazz. She submerges into the hypnotic music: "In the café, under the underground railings we climbed down to drink the bubbles of jazz in the shameful light of candles; and we sat just like in the deep grass, soaked in the rhythms" (Zemdega 1968). On the other hand, observing the youthful carnival in Los Angeles Nagys identified only aggressive and destructive energy, focused on the artefacts of culture ("Stained glass windows crumble and shop windows split”, “Trupa vitražų stiklai ir skyla vitrinų stiklas”); the real musicians and the audience were replaced by the anonymous coloured angels who danced "on stars and broken glass".

The broken glass was recalled as a metaphor of fragmented existence in the poem "Without Name" / "Uz ielas nejauši uzskatiju..." by Salin̦š (first published in his collection Melnā saule, Brooklyn, NY, 1967). It lies on the street of New York City reminiscent of a piece of lost sky and reflecting the subject's identity. That bleak image evokes many doubts because the observer and the reflection are not of the same origin: "And perhaps there was not me - how could I know what would be my appearance in heaven?” (Saliņš 1968). The poets of exile meditate on the broken world where metaphysical illusions are denounced and the artists themselves look like ghosts.

The exiled person feels lonely in the big world; nevertheless he can travel where he wants. He can admire different countries while not suspending his individual point of view. Nagys wrote poetical letters to the imaginary addressees: to the dissident martyrs of the Budapest anti-Soviet revolt of 1956, to the African native hunters of the colonial Golden Coast, to the daughters of Hong Kong fishermen. He was attentive to Latvian poetess Astrīde Ivaska (1926-2015) and to her cosmopolitan impressions from the famous European landmarks. For instance, the Latvian poetess restored an idyll of the Mediterranean island of Paros where death turns into painless sleep: "It is good to live in the island of Paros where the old people die looking at the sea" (poem "In the Island of Paros (Greece)", Ivaska 1968). Ivaska and her husband, a mediator of the different languages and cultures, Estonian researcher and professor of Oklahoma University, editor of the literary magazine Books Abroad and multilingual poet Ivar Ivask (1927-1992) shared her Eurocentric views. Ivaska admitted that four countries: Austria, Spain, Greece, and Finland and their poets taught her to realize what was life and death (Gaižiūnas 2007: 11). 
In Nagys' poetry there are occasional allusions to the European "must-see" sites, but those visions of foreign lands never wake up memory; they recall the touristy snapshots, and the myth of primordial paradise might be restored in them: "In the legendary island of Capri one can find slim jugs and women. [...] In the legendary island of Capri children bring the sun in their handfuls" ("Legendarinej Capri saloj ąsočiai liekni ir moterys. / [...] Legendarinejj Capri saloj vaikai neša saujose saulę") (poem “Capri”, Nagys 1990: 148 [1958]). Nagys was concerned about his native Lithuania but other countries evoked no nostalgia in him and they were important insofar as they recalled his native experience. Meditating on Capri, Nagys could not forget his colleague who was related to Italy. Juozas Kèkštas (1915-1981) was a representative of the Žemininkai movement; during World War Two he fought in the Polish Armed Forces in the West that fought against the Nazis in Italy but in the post-war years he moved to Argentina and died in Poland: "My friend poet sang about the broken sun in the dust of the noon" ("Dainavo mano draugas poetas / sutrupinta saulę vidurdienio dulkèse"). Historical traumas left their imprint on the poetical imagination of Nagys: he could not meditate on the exotic or foreign landscape indifferently; Latvian poets seem to be more open to the visual impressions and more cosmopolitan.

In his later texts Nagys turned to interpretations of folklore. Semantic isotopes of flying god-like beings could be discovered in them: we can distinguish the mythic Aitvaras (literally, Kite, the flying god of fortune) or Sakalas (Falcon) "with eyes of amber". Nagys emphasized the semantics of the North which was related not only to the arctic Canadian landscapes but also to the topography of Lithuania and Latvia, presuming prehistoric deep links. As the critic Šilbajoris later summarized, "A final embodiment of this mystique is the Northern Star around which turns the constellation of the Great Bear, always pointing North that now comes to symbolize the friendship of the free and brave as well as the longing to be back home under the Northern sky. All this may, after all, be a different form of other writers' nostalgia, born of dispossession" (Šilbajoris 2002: 127). Nagys was called the "Sibelius of Lithuanian poetry" by the world-famous anthropologist Marija Gimbutas (Visvydas 1981: 196) because the motifs of the North were evident in his poems, the spatial perception inspired metaphors, and the northern landscape was often meditated as a distinctive symbol. The free verses recall the symphonies of the Finnish composer. For Nagys, the North was the metaphysical, eschatological home which should be re-discovered by all post-war Baltic émigrés at the end of their life-long journey.

In the snow-covered north the concepts of death and loss are reflected. In the "Elegy for Algimantas" ("Elegija Algimantui", Nagys 1990: 222 [1964]), commemorating the tragic fate of the émigré poet Algimantas Mackus (1932-1964), 
the archaic rhythm of the funeral laments was recalled; and this nostalgic and yearning rhythm correlated with the wide, ascetic, empty and soundless landscape which resembled the image of homeland: "Now only now / when the first snow falls / of autumnal Sunday in the north / through naked branches of Canadian forest / into the blue and cold lake / now only now I know / I believe I bring myself to believe / you live no longer in our land and in our midst" ("Dabar tiktai dabar / kai krinta pirmas rudenejjančio sekmadienio / ir šiaurèj sniegas / pro nuogo nulapojusio Kanados miško / šakas ị mėlyną ir šaltą ežerą / dabar tiktai dabar žinau / tikiu prisiverčiu tikèti / tavęs nebèra mūsų žemèje ir mūsų tarpe"). Mackus, recognized as a promising poet of the younger generation, contemplated the fragmentation of the exile's consciousness and decline of native language. He lost his life in a car accident and his death became the symbol of disintegration and irretrievable loss of the diaspora. All the expatriates are inevitably touched by the same destiny: "perhaps in the small pub / near the chapel of the dead / a bitter glass of vodka / will be our last / farewell" ("gal mažytèj smuklèj / prie mirusių koplyčios / kartus degtinès stiklas / bus paskutinis mudviejų / sudie").

Alcoholic dizziness replaces the remedies and amusements, they mediate between physics and metaphysics: an intoxicating cocktail reminds one of dead friends, about the forthcoming rendezvous in the imaginary agnostic Elysium. In Saliņš' poems sentimental moods were eliminated; Nagys' texts, on the contrary, were full of sentimentality as they were influenced by the emotionally intense Expressionist poetics. In the short poem by Saliņš “After the Last Drop” / "Pēc beidzamās lāses" which was translated by Nagys, the atmosphere of a suburban pub was restored: the dead dreams and friends had been recalled at the end of the party that turned into a funeral banquet, and the approach of death was experienced in a calm and dignified manner: "The last drop. We eat the cherries, and cocktail soaked into them as deeply as into us. We remember the dead dreams and friends. Every moment someone of us disappears - it seems that someone goes [to the place] where the dead had been lost - it seems that the hour is approaching when we would have to meet" (Saliňš 1968). This is the kind of Northern-style temperament when the subject tries to make peace with his austere existence.

\section{Contemplating the Archaic Heritage}

Many researchers who review the Latvian poetical tradition pay attention to its folklore-based roots which are more evident than those of Estonian and Lithuanian poetry. Those roots were newly acquired in exile: during the period of 
1952-56 a collection of 12 volumes of Latviešu tautas dziesmas was published in Copenhagen, and it was significant not only as a monument to dying tradition but also as direct source of inspiration for the Modernist literature. Ivar Ivask has noted that the pagan rituals of fertility were still alive in the Latvian and Lithuanian sub-conscious in the contemporary era (Ivask 1973: 9). Nagys discussed the Baltic identity, reconstructing the archaic and idealized epoch of a unified nation when the mythical state of Dainava existed and "the song was stronger than death" (poem "Diary" / "Dienoraštis", Nagys 1990: 207). The ancient dual forms of grammar were used because the subject immortalizes himself in history alongside his alter ego, psychoanalytic reflection, imaginary brother: "We both exchange the amber"; "Spring is our brother" ("Mudu mainom gintarą; Pavasaris mudvieju brolis", ibid. 209). There was the utopian golden age when brotherly ties linked Baltic nations. Amber was contemplated as a magical stone or as "stagnant sun".

Astrīde Ivaska also envisioned the Baltic seaside landscape not as the savage and timeless space but as a historically encoded place. In her poem "Fishing Nets" the sea preserves its historical discourse which can be conceived only by those who had been born on this shore. The stormy sea can immerse a traveller in its complicated reflections of the past: "I was successful to be born by the gulf where the land is old and the sea is even older. The waves weave fishing nets and pull me back into the past centuries..." (Ivaska, Ivask 2007: 45). In fact, the cosmopolitan, Eurocentric poetess Ivaska was deeply affected by the moods of nostalgia and metaphysical longing: "The impressions from the outer world as they filter through the dear souvenir from Latvia evoke nostalgic and meditative moods [in Ivaska's poems] that are imbued with warmth and intimacy of a very personal presence which is so closely felt because it is self-effacing, sincere, and humble" (Silenieks 1972).

Nagys appreciated the works of folk poets which were full of mythical signs and never emphasized the distinction between nature and culture. Those prehistoric, pan-Baltic times of Dainava were full of harmony; metaphors of poetry had been recognized in the primitive shapes of nature. In his "Baltic" poems Nagys seems to be alienated from the Catholic tradition and from the idea of the Word incarnating into the Body. Words were interpreted as material things; they meant vitality, energy, and the restored pantheistic ideology: "every word folded as a bud, as a leaf glittering in the sun, swinging in the wind, and being washed by humble and warm rain" (poem "Folk Poets Have Created...") ("kiekvienas žodis skleidèsi / kaip pumpuras, kaip lapas, / žèrèdami saulèj, / linguodami vejjuj, / plaunami nuolankaus / ir šilto lietaus”, "Liaudies poetai sudèjo...., Nagys 1990: 200 [1965]). 
The creative power of nature was also emphasized by Velta Sniķere (b. 1920), a Latvian poetess who was interested in Indian Yoga and Oriental philosophy. She studied traditional Indian dance and felt lonely and alien to national Latvian literature with her meditative and universal lyricism. Ivaska in her review of Latvian post-war poetical tendencies asserted that Sniķere's style (known from her collection of poems Nemitas minamais, Chicago, 1961) had been so individualistic and esoteric that she had no followers (Ivaska, Ivask 2007: 22). Nagys was impressed by Sniksere's short poetic sketches. For example, he translated the poem "Don't Pass-By Not Raising" / "Nepaej nepacel̦ot": here human destiny was contemplated not as the heavenly arbiter's punishment or grace but as a challenge of nature. Destiny is represented as an obstacle on the personal way, created by one's personal will: "We disseminate forward our unfulfilled destiny; and it branches out, comes into leaves and meets us at its thicket" (Sniķere 1968). Destiny is a law of nature rather than metaphysical fate.

In Sniķere's poetry, inter-subjective communication is very intimate: the lyrical subject is amalgamated with the addressee, and the mystical forms of sensual perception are acquired: "You suddenly were so close to me / that I couldn't see you / like my hand in the mist" (poem "You Suddenly Were So Close..." / "Tu man pēkšn,i biji tik tuvu...”). Nagys meditated on this situation without erotic allusions; such a close, painful contact linked his lyrical subject to a sister: "You are so close that it hurts" (poem "Sister") ("Tu taip arti, kad net skauda", "Sesuo", Nagys 1990: 274 [1976]). Nagys often emphasized the solidarity with brothers, sisters and friends; he convinced his audience that he had the exceptional right to speak in the name of humiliated and enslaved people, of those who were put to silence by totalitarian regimes: "And speak only to them and only for them. / Make yourself the mouth of a mute and the eyes of a blind person" (poem "Never Sell Yourself...") ("Ir kalbèk tik jiems ir tik už juosius. / Būki nebylio burna ir neregio akim", "Niekad neparduok savęs...”, ibid. 242 [1977]). He never took responsibility for a politician, his verses, however, reflected the mix of patriotic activism and egocentric meditations. Nagys' poems could be characterized as private and at the same time extremely social. The position of Snikere was not so declarative, though she also tried to overcome the common disability of senses and to discover new, unexperienced worlds and the pulse of vitality in nature: "Sometimes [one needs to] show to the blind one, to whisper to the deaf one..."

Latvian exile poetry, as it could be seen from the quoted translations of $\mathrm{Na}$ gys, might be evaluated as very "feminine" and feminist: it is dominated by sensual and vital elements; it seems to be full of matricentric mythology and a subtle perception of beauty. Nagys appreciated such kind of "écriture feminine", although the metaphorical field of his own vision was full of masculine symbolism, heroic, military tendencies, and the pathos of struggle. Latvian exile poetry 
and its sudden prosperity in the 1960s was for him an important argument proving that even under émigré conditions the literary revival was possible. It was hard for him to reconcile himself with the inevitable downfall of literature in the native language of the diaspora. He hoped that Lithuanian poetry, just like the language itself, had reached a high level of perfection and could not go into decline. He defined the current dynamism of Lithuanian poetry metaphorically as "a torrent of the great river" (Platelis 1995: 135) and considered it an ambiguous (destructive and creative) force.

For Nagys, there were many poets whom he regarded as trail-blazers: Kristijonas Donelaitis, Vincas Mykolaitis-Putinas, Aistis, Rilke, Georg Trakl. Among the poets who deserved the status of pioneers he never mentioned Latvians: he considered them colleagues and counterparts, sometimes rivals, but never praised them as geniuses or exceptional pathfinders. In 1953, already under the conditions of exile, Nagys wrote a concise but comprehensive review of Latvian poetic trends for the influential magazine Literatūros lankai, mentioning major names, beginning with Juris Alunāns from the middle of $19^{\text {th }}$ century up to the greatest names of the interwar Modernist generation which perished in the catastrophic whirlpools of the totalitarian era - Jānis Medenis, Aleksandrs Čaks, and Eriks Ādamsons. The major literary journals were also mentioned, especially those which played significant roles in the dialogue of modernist and conservative authors. In his review Nagys sought to ignore ideological prejudices, stressing the significant role of socialist intelligentsia in the interwar Latvian culture (Nagys 1953: 24). In the early 1950s, some years before the establishment of the "Hell's Kitchen" group, Nagys evaluated the Latvian poetical tradition a little bit sceptically. He noted the warnings of some modernist interwar Latvian poets about the threat of stagnation and recurrence. According to him, the Latvian language at the beginning of the $20^{\text {th }}$ century was not resonant and flexible enough and not quite suitable for classical poetical forms, but Latvian poets adequately demonstrated their masterful skills and their power of imagination to revive their creative traditions ( $i b i d$.). Such a generalizing interpretation certainly expresses the private opinion of the Lithuanian poet (with all stereotypes and prejudices) who was familiar with Latvian Modernist poetry but his scale of aesthetic values had been primarily balanced by Lithuanian NeoRomanticism and German-Austrian Expressionism.

\section{Conclusions}

The poet and translator Nagys was a genuine mediator of related though not congeneric traditions. He was reluctant to identify himself with a specific region, 
however, the austere Northern and Samogitian landscapes defined his identity in metaphorical forms. Nagys was influenced by Western Expressionism which was reinvented in the post-war artistic and critical communities, however he was loyal to the patriotic and civic principles which had been typical of the conservative Lithuanian diaspora in the West. He regarded the creative work of a poet as a special mission and was a successor of (sometimes regarded as an anachronism but still popular in the post-catastrophic age) the Romantic cult of "genius". The balance of private regionalism and public nationalism was obvious in his poetical landscapes: the regional place-names revealed the private memory as the source of metaphorical inspiration, and this memory integrated itself with the broader contexts of national, Baltic and Northern identity. The fundamental opposition of the steady and dynamic values was contemplated in Nagys' poems. There is some kind of a cultural clash: the agrarian consciousness rooted in the native soil $v s$. the nomad consciousness dreaming of railway-stations and lighthouses in the seaports. Urban culture was equalized to the nomad existence, the traumatic fate of the post-war refugees.

The Latvian element of identity was interpreted in Nagys' poems as a distant flashback from the past related to the image of the mother or to the matricentric heritage in general. The poet was native of the boundary region of Mažeikiai, near the Lithuanian-Latvian border; however it is difficult to discover obvious Latvian traces in his works apart from literary influences. The boundary landscape was not recognizable as specifically Lithuanian or Latvian but it was meditated as a partly mythological space of a private Arcadia which was contemplated after its loss and alienation. The city of Liepāja was remembered as the visual image in the shape of an old-fashioned "postcard" where the interior view of a children's room and the panorama of the port had been blended. The intimate reflections correlated to the public space; for Nagys, Latvian landscape looked urbanized, civilized and at the same time sentimental.

Careful comparative studies may reveal inner links of Nagys' stylistic breakthrough in the collection Melynas sniegas (Blue Snow, 1960) and Latvian avantgarde poetics of the 1950s. Urban civilization with all its depression and despair invaded the devastated horizon of an exiled subject; in the face of threatening mors atomica the poets offered their fictional vision instead of reality. The Latvian Gunars Saliņš was obsessed by plans to reforest New York City in order to change the depressing image of the "Hell's Kitchen" district and Nagys created his "land of Blue Snow", "Homeland of a Falcon", the mythic and utopian idyll of the "Baltic Dainava". At the same time he developed his ironic relationship to the civilized reality, revealed the grotesque vision of the nuclear era of total dehumanization. His terra incognita had been the desacralized, totally mundane post-catastrophic space which would be the last shelter after the global collapse. 
The reasoned pessimism of both Nagys and Saliņš proved the relativity of all the values: only losses are permanent, and we do not know how our image will be reflected in heaven (according to Salinšs). The final result of the modern dehumanization of society will mean total oblivion and amnesia.

The imaginary landscapes gave Baltic exiled poets the illusion of liberation which was expressed in a musical form. Rhythms of jazz and dances of barefoot angels represented the fragmented decadent culture. Nagys' subject felt related to the underground, protest movements though in this Nagys was not as enthusiastic as his contemporary Jonas Mekas. The author of Melynas sniegas was influenced by Western avant-garde that appreciated the method of jazz improvisation; though Nagys, unlike the Latvian poetess and professional musician Aina Zemdega, regarded the apparent freedom of expression (which was emphasized in jazz and pop music) as the feature of cultural downfall.

The poet tried to escape from the hermetic cultural ghetto of the diaspora and was interested in the exotic "savage" aboriginal communities which had a chance to escape from global catastrophes in secluded islands. When he recalled European landscapes, they appeared in the context of post-war exile: even the colourful island of Capri was only a setting for reflections upon his fellow poet Juozas Kèkštas and his heroic fate. The imaginary country of pre-historic Dainava referred to the dreams of Pan-Baltic solidarity. Nagys came back to his folklore roots, allegedly having been influenced by the folk-oriented tradition of Latvian lyricism.

Nagys' elegiac poems dedicated to his perished friends, "brothers white kites", were pathetic and emotionally intense, meanwhile the Latvian poets whom he translated usually avoided the sentimentality, and their verses on the topic of irretrievable loss expressed Protestant sobriety and moderation or (as in the case of Velta Snikgere) Orientalist meditation on the relativity of all authorities. Nagys' lyrical subject tried to match the legendary folk poets for whom "the song was stronger than death". His pathetic statement on the immortality of the word referred to the Neo-Romantic and Nietzschean myth of genius. Nagys preferred to speak in the name of his generation, diaspora and nation; his rhetoric was explicitly historical and socially-oriented. Historical consciousness is also inherent in the poetry of Astrīde Ivaska who metaphorically characterized the Baltic seaside as "the old land and even older sea". Lacking emotional pathos, Latvian poetical images which were translated by Nagys represented the universal folklore archetypes without specific means of stylization. Nagys never tried to idealize Latvian poetical trends although he absorbed their main semantic patterns: the pure "de-metaphorized" images, poetical reflections of folklore, the agnostic or pantheistic worldview. 
Henrikas Nagys as a Mediator of Lithuanian and Latvian Poetical Traditions

\author{
Manfredas Žvirgždas \\ manfredasz@gmail.com \\ Lietuvių literatūros ir tautosakos institutas \\ Antakalnio g. 6 \\ LT-10308 Vilnius \\ LIETUVA
}

\title{
Bibliography
}

Aistis, J. 2004. Raštai, III. Homer Glenn, IL: Ateities Literatūros Fondas.

Antanaitis, A. T. 1970. Aitvaro brolio neišdaviau. - Aidai, 9, 397.

Butkus, V. 2008. Literatūros topografija: (poli)metodologinès trajektorijos. - Colloquia, $21,11-29$.

Butkus, V. 2011. Literatūros topografija: lietuviškoji patirtis ir jos kontekstai. Colloquia, 26, 36-61.

Gaižiūnas, S. 2007. Du balsai iš Rygos. - A. Ivaska, I. Ivask, Skraidantis ežeras. Vilnius: Pasviręs pasaulis, 5-13.

Ivask, I. 1973. Baltų egzilio literatūra. Šimtmečio ketvirčio apžvalga. - Aidai, 1, 2-10.

Ivaska, A., Ivask, I. 2007. Skraidantis ežeras. Ed. by S. Gaižiūnas. Vilnius: Pasviręs pasaulis.

Ivaska, A. 1968. [Alhambra; Paro saloj (Graikijoje); Ne žaibas, bet karas.] - Aidai, 9, 394.

Jonynas, V. A. 2006. Rinktiniai raštai. Vilnius: Lietuvių literatūros ir tautosakos institutas.

Kaupas, J. 1963. Introducing the Poetry of Henrikas Nagys. - Lituanus, 9, 3. -http:// www.lituanus.org/1963/63_3_04.htm (06.12.14).

Kraujiete, A. 1968 [Poetui, kurị mylèjo sodai.] - Aidai, 9, 393.

Nagys, H. 1953. Latvių poezija. - Literatūros lankai, 3, 24.

Nagys, H. 1963. [Poems, translated into Eglish by A. and R. Page]. - Lituanus, 9, 3. http://www.lituanus.org/1963/63_3_04.htm (06.12.14).

Nagys, H. 1990. Grįžulas. Poezijos rinktinè. Vilnius: Vaga.

Nagys, H. 1991. Niekad nebuvau emigrantas. - Literatūra ir menas, 1991-11-16, 11.

Nyka-Niliūnas, A. 1996. Temos ir variacijos. Literatūra / Kritika / Polemika. Vilnius: Baltos lankos.

Nyka-Niliūnas, A. 1998. Alfonsas Nyka-Niliūnas: Pavadinti daiktus tikraisiais vardais. - Šiaurès Atènai, 7, 3.

Paplauskienè, V. 2009. Liūné Sutema: Gyvenimo ir kūrybos keliais. Kaunas: Naujasis lankas.

Platelis, K. 1995. Tartum didelès upès srovè. - Metai, 8-9, 134-138.

Saliņš, G. 1968. [Po paskutinio lašo.] - Aidai, 9, 393.

Schulte, R. The Translator as Mediator between Cultures. - Dallas: University of Texas, http://translation.utdallas.edu/essays/mediator_essayl.html (06.12.14). 
ŽVIRGŽDAS

Silenieks, J. 1972. Latvian literature in exile: The Recycling of Signs. - Lituanus, 18, 1. - http://www.lituanus.org/1972/72_1_03.htm (06.12.14).

Sniķere, V. 1968. [Nepraeik nepakèlęs; Tu staiga man buvai taip arti; Esu balsas; Žinodamas.] - Aidai, 9, 393.

Sutema, L. 2009. Sugrizžau. Poezijos rinktinè. Vilnius: Lietuvos rašytojų sąjungos leidykla.

Šilbajoris, R. 1970. Perfection of Exile: Fourteen Contemporary Lithuanian Writers. Norman: University of Oklahoma Press.

Šilbajoris, R. 1982. Poetic Text and Human Feeling in Gunars Saliņš and Henrikas Radauskas. - Journal of Baltic Studies, 13, 2, 91-97.

Šilbajoris, R. 2002. A Short History of Lithuanian Literature. Vilnius: Baltos lankos.

Visvydas, P. 1981. Sibeliškas sakalo skambejimas. - Aidai, 3, 196-197.

Zemdega, A. 1968. [Pasivaikščiojimas]. - Aidai, 9, 394. 